\title{
The Effect of Financial Leverageas a Financial Distress Factor on Financial Performance on Commercial Banks in Kenya
}

\author{
${ }^{*}$ Fred O. Sporta ${ }^{1}$, Patrick K. Ngugi ${ }^{2}$, Patrick Ngumi ${ }^{3}$, Christine S. Nanjala ${ }^{4}$ \\ ${ }^{1}$ Department of Commerce and Economic Studies,Jomo Kenyatta University of Agriculture and Technology, \\ Kenya. \\ ${ }^{2}$ Department Of Entrepreneurship and Procurement,Jomo Kenyatta University of Agriculture and Technology, \\ Kenya. \\ ${ }^{3}$ Department of Commerce and Economic Studies Jomo Kenyatta University of Agriculture and Technology, \\ Kenya. \\ ${ }^{4}$ School Of Business, KCA University, Kenya. \\ Corresponding Author: Fred O. Sporta
}

\begin{abstract}
This study attempted to determine the effect of financial leverage as afinancial distress factor on financial performance of commercial banks in Kenya. Secondary data was used in a census commercial banks from 2005 to 2015 was extracted from financial statements of 38 commercial banks out of the possible 44 commercial banks in operation as at $31^{\text {st }}$ December, 2015 in accordance to CBK as a regulatory body. Data was collected from 2005 to 2015.descriptive and analytical design was adopted. The results show perfect positive correlation between debt equity ratio with return on equity andreturn on assets as well return on equity.The study was limited to the commercial banks in Kenya, the findings were only interpreted tocommercial banks in Kenya and they will not be generalized for all financial institutions.
\end{abstract}

Keywords; Financial Leverage, Financial Performance and commercial banks.

\section{Introduction}

Financial leverage is traditionally viewed as the use of borrowed money in the firm capital structure, through the use of fixed income securities, such as: loans \& bonds. Generally, increased leverage results increase in retunes and risk, whereas decreases in leverage results in decreases in returns and risk. However, the use of leverage is associated with two different possible outcomes either positive (maximizing the profit) or negative (minimizing the profits, and putting the company at risk because of the high debt \& risk level).Leverage is a variable used to examine the effect of change in leverage on the firms' performance (Saleh, 2015). Saleh (2015) argued that changes in leverage also have a significant effect on firm's performance; financial firms should use their debt financing more efficiently in order to maximize their returns and performance. Saleh (2015) suggested that financial leverage is the most important determinant of companies' performance after the crisis (2008-2012). Financial leverage affected companies' performance significantly and negatively for both, before and after the crisis periods. The increase of debt financing during the financial crisis period implied that the debt financing made firms more susceptible to refinancing risks and borrowing at higher costs which in turn decreases their performance (Saleh, 2015).

Foong (2012) suggested that leverage is negatively associated with firm performance, however, there is a significant interaction effect between leverage and product diversity on firm performance. Foong (2012) noted that leverage could be beneficial or detrimental to the financial performance of general insurance firms, contingent on the extent of product diversity of the firm. Highly leveraged companies tend to invest less in employee-orientated activities which in turn lead to higher levels of leverage thus increasing the company's risk (Wieland, Scott, Wieland, \& Flavel, 2015).Kosikoh (2014) argued that highly-leveraged firms are more likely to respond financially; through dividend cuts, debt restructuring, and bankruptcy thus there is high relationship of leverage and financial distress. Kosikoh (2014) further showed that highly levered firms respond faster to minimize implication of poor performance. This study will look at consider leverage as one of the financial distress factor as possible influences of financial performance of financial institutions. According to Nyamboga,Ongesa,Omwario, Nyamweya,Muriuki and Murimi (2014) higher leverage ratio means a higher proportion of debt compared to equity in long-term financing. While higher leverage would boost return on investment in favorable business conditions, higher leverage would, on the other hand, adversely affect return on investment during unfavorable business conditions(Nyamboga et al., 2014). This study hypothesizes that; 
Ho: Financial leverage does not affect financial performance of for commercial banks in Kenya.

The paper is organized as follows: section, section 1, Introduction, section 2, literature review. Section 3 discusses the methodology. The empirical analysis and results are presented in section 4. Section 5 concludes the study and provides recommendation for future studies.

\section{Trade off theory}

\section{Literature Review}

Modigliani and Miller (1963) argued that the tax code favors debt over equity financing by allowing the firm's interest expense to be deducted from gross income for corporate tax purposes, but disallowing deductibility of payments to equity holders (e.g., dividends are not tax deductible on the personal account). Since an additional dollar of debt generates the marginal benefit of a tax deduction without any offsetting cost in this framework, the firm value is maximized by utilizing as much debt as possible to finance corporate investment decisions. Other financial economists, such as (Kraus \& Litzenberger, 1973), suggested that the costs of financial distress might provide reconciliation between the observed limits on the usage of debt and the predictions of the tax-adjusted Modigliani-Miller analysis of financial policy.The trade-off theory asserts that leverage has potential benefits to the firm due to tax savings associated with use of debt. However other studies have noted that with higher leverage, volatility of share prices increases with respect to private information; the ultimate fate of the firm depends on issues unknown to the general public (Nyamboga, Omwario \& Muriuki, 2014).

\section{The Pecking Order Theory}

Pecking order theory was first suggested by Donaldson in 1961 and it was modified by Stewart C. Myers and Nicholas Majluf in 1984. It states that companies prioritize their sources of financing (from internal financing to equity) according to the cost of financing, preferring to raise equity as a financing means of last resort. Hence, internal funds are used first, and when that is depleted, debt is issued, and when it is not sensible to issue any more debt, equity is issued (Stewart \& Nicholas, 1984). The pecking order theory does not take an optimal capital structure as a starting point, but instead asserts the empirical fact that firms show a distinct preference for using internal finance (as retained earnings or excess liquid assets) over external finance, (Stewart \& Nicholas, 1984). If internal funds are not enough to finance investment opportunities, firms may or may not acquire external financing, and if they do, they will choose among the different external finance sources in such a way as to minimize additional costs of asymmetric information. According to Majluf and Myers (1984) the resulting pecking order of financing is as follows: internally generated funds first, followed by respectively lowrisk debt financing and share financing.

In Majluf and Myers (1984), suggests that other potential investors in the market will always rationally discount the firm's stock price when managers issue equity instead of riskless debt. To avoid this discount, managers avoid equity whenever possible (Stewart \& Nicholas, 1984). The Myers and Majluf model predicts that managers will follow a pecking order, using up internal funds first, then using up risky debt, and finally resorting to equity. In the absence of investment opportunities, firms retain profits and build up financial slack to avoid having to raise external finance in the future (Stewart \& Nicholas, 1984). This theory therefore strongly indicates that use of leverage will be less costly as compared to use of equity, this further means that use of leverage will enhance better financial performance firms and may not involve too much costs unlike other forms of sources of finance in addition use of cheaper sources of finance like retained earnings is less likely cause financial distress. However on the other hand leverage will be easy to access but repayments schedule may result to financial distress. This theory firmly confirms that leverage is a financial distress factor that will influence financial performance of a given firm.

\section{Empirical review}

The studies which discuss the relationship between corporate financial distress and leverage ratios and financial performance have frequently contradicted their findings. Some studies have concluded the a positive relationship for example Opler \& Titman (1994) while others indicated a negative or lack of a relationship, for example Pranowo and Manurung (2010). Anjum and Malik (2013) examined determinants of corporate liquidity and extent size of the firm, net working capital; leverage, cash conversion cycle and sales growth affect the cash holdings of corporate organizations, Anjum and Malik (2013) evaluated the financial difficulties of Pakistanis firm that was listed on Karachi Stock Exchange (KSE). The non-financial companies from 2003 to 2010 were used as the sample and the analysis was done by using Z-score model. The results concluded that the leverage is positively significant to the financially distressed firms in Pakistan's stock exchange and it suggests that the use of a high level of leverage contributes to the bankruptcy. This study therefore identified that leverage is a key financial distress factor. However the study did not determine the effect of leverage as a financial distress factor on financial performance and in addition it was mainly based on Pakistanis firms and not Kenyan banking 
industry. Okello (2015) examined the determinant of financial risk of listed companies on the NSE in Kenya, questionnaires and interviews were used to capture both qualitative and quantitative data from management of the listed companies under consideration. Okello (2015) concluded that leverage was the strongest determinant of the financial risk of the listed companies and could easily influence financial distress in listed companies in Kenya since more debt financing implies higher possibilities of default hence higher risk. Okello (2015) only linked leverage as a risk factor on the listed companies in NSE and not on banking industry while Omondi and Muturi (2013) noted that leverage has significant negative effect on financial performance. The current study therefore identifies leverage as a key financial distress factor and as will determine the effect it has on financial performance of Kenyan banking sector, specifically commercial banks. Kosikoh (2014) sought to establish determinants of financial distress factors on insurance companies in Kenya. The study used a descriptive design on 45 insurance companies registered by Insurance regulatory Authority in Kenya as at $31^{\text {st }}$ December 2013. Kosikoh (2014) concluded that there exist a positive relationship between leverage and financial distress on Insurance companies in Kenya. However the study only emphasized on the relationship between leverage and financial distress for insurance companies in Kenya but not on its effect as a financial distress factor in banking industry in Kenya. Nyamboga,Ongesa,Omwario,Nyamweya,Muriuki and Murimi(2014) examined the determinants of corporate financial distress of non-financial firms in Nairobi security exchange, among them was leverage being a determinant of financial distress, the study used descriptive research design and quantitative data was collected from the financial statements of 38 non-financial companies, according to the study leverage was found to be having no significant influence on corporate financial distress. However the study was based non-financial firms listed in NSE and not financial firms especially commercial banks in Kenya.

\subsection{Data collection}

\section{Methodology}

Data on the variables was collected by use of secondary data mainly from financial statements of individual commercial banks in Kenya under study, the data collection covered 11 year period from 2005 to 2015 , these period of eleven years was selected for the study in order to establish the changes in commercial bank over time and to base the analysis on as recent data as possible. This could also be important since several banking regulations for financial institutions had been put in place.

\subsection{Data processing}

According to Blumberg, Donald Cooper and Schindler (2014) data processing involves editing coding, classification, tabulation and graphical presentation. The study extracted data containing quantitative details from financial institutions, the panel data collected was analysed quantitatively through a mathematical and regression equations and this was solved by using a statistical tool(STATA).

\subsection{Regression}

Financial performance was regressed against Financial leverage. Other independent variables that were also included in the current study include; liquidity, operational efficiency, asset quality and capital adequacy, the following is a multiple statistical model that determined the effect of operational efficiency and other independent variable on financial performance of commercial banks.

$\mathrm{ROE}_{\mathrm{it}}=\mathrm{a}+\beta_{1} \mathrm{LIQ}_{1 \mathrm{it}}+\beta_{2} \mathrm{LEV}_{2 \mathrm{it}}+\beta_{3} \mathrm{OPE}_{3 \mathrm{it}}+\beta_{4} \mathrm{ASQ}_{4 \mathrm{it}}+\beta_{5} \mathrm{CAD}_{5 \mathrm{it}}+\mathrm{e} \quad$ (Equation 1) $\mathrm{ROA}_{\mathrm{it}}=\mathrm{a}+\beta_{1} \mathrm{LIQ}_{1 \mathrm{it}}+\beta_{2} \mathrm{LEV}_{2 \mathrm{it}}+\beta_{3} \mathrm{OPE}_{3 \mathrm{it}}+\beta_{4} \mathrm{ASQ}_{4 \mathrm{it}}+\beta_{5} \mathrm{CAD}_{5 \mathrm{it}}+\mathrm{e} \quad$ (Equation 2)

The current study will use debt to equity ratio (DER) and debt to assets ratio (DAR) to measure leverage, where DER for commercial banks will be determined by total liabilities divided by total market value of assets, DER reflects the company's ability to meet all its obligations, which is indicated by what proportion of equity capital used to pay the debt. In other words, this ratio is used to determine what portion of any equity capital as collateral for overall corporate debt or to assess the amount of debt used by the company (Heikal, Khaddafi, \& Ummah, 2014). while Debt to assets Ratio is determined by dividing total liabilities by total assets, the higher the ratio the more the financial distress in the firm (Fan, Titman, \& Twite, 2012).ROA (return on assets) as a measure of profitability was expected to have a positiverelationship with efficiency since highly profitable banks are more efficient(Wang'ombe, Muturi, \& Ngugi, 2016).The study used retun on assets(ROA) and return on equity (ROE) as measures for financial performance. ROA is an accounting measure of bank's overall perfromance since its definations is based on net income over total assets of a firm and therefore shows the profit earned dollar of assets, It is an indicator of bank"s efficiency and a measure of the bank"s ability to earn rent from its total operations. The ROE, on the other hand, reflects how effectively a bank management is using shareholders" investment. It tells the bank"s shareholders how much the institution is earning on the book value of their investment (Arif, 2012).In fact, ROE is the most important measurement of banking returns because it is influenced by how well the bank is performed on all other return categories, and indicates whether a bank can compete for private sources in the economy. ROE is defined as net income divided by average equity. 


\section{Results And Discussion}

\subsection{Descriptive analysis of operational efficiency}

The first indicator of the companies leverage was the measure of the debt equity ratio. The debt to equity ratio used in the study was determined by total liabilities divided by total market value of assets, DER reflects the company's ability to meet all its obligations, which is indicated by what proportion of equity capital used to pay the debt. Based on the means the banks seem to keep low debt to equity ratios across the years with standard deviations $0.039,0.023,0.022,0.085,0.128,0.129,0.409,0.552,0.631,0.566$ and 0.302 respectively for the years.

Table 4. 1: Debt to Equity ratio

\begin{tabular}{|c|c|c|c|c|c|}
\hline Year & Obs & Mean & Std. & Min & Max \\
\hline 2005 & 38 & 0.007 & 0.039 & 0.000 & 0.226 \\
\hline 2006 & 38 & 0.004 & 0.023 & 0.000 & 0.130 \\
\hline 2007 & 38 & 0.006 & 0.022 & 0.000 & 0.115 \\
\hline 2008 & 38 & 0.032 & 0.085 & 0.000 & 0.314 \\
\hline 2009 & 38 & 0.050 & 0.128 & 0.000 & 0.497 \\
\hline 2010 & 38 & 0.041 & 0.129 & 0.000 & 0.658 \\
\hline 2011 & 38 & 0.157 & 0.409 & 0.000 & 1.676 \\
\hline 2012 & 38 & 0.251 & 0.552 & 0.000 & 2.316 \\
\hline 2013 & 38 & 0.281 & 0.631 & 0.000 & 2.467 \\
\hline 2014 & 38 & 0.312 & 0.566 & 0.000 & 2.708 \\
\hline 2015 & 38 & 0.200 & 0.302 & 0.000 & 1.219 \\
\hline
\end{tabular}

As shown in table 4.2, the overall mean debt to asset ratio was 0.1219 with a standard deviation of 0.361. The minimum debt to asset ratio ever kept by any firm across the years 2005 to 2015 was 0.000 which were found in 2005 and 2015. The maximum possible debt to asset ratio ever kept by any of the firms in study was 2.708 in 2014. Debt to asset ratio has a high standard deviation within panels than between panels. This indicates that there is a high risk preference on debt to equity ratio as a financial distress factor to performance for every commercial bank over years as compared to financial distress risk as caused by leverage across the 38 commercial banks, since higher standard deviation indicate high risk.

Table 4. 2: Overall descriptive analysis for Debt to Equity ratio

\begin{tabular}{lllllll}
\hline & & Mean & Std. Dev. & Min & Max & Observations \\
\hline Debt Equity ratio & Overall & $1.219 \mathrm{E}-01$ & 0.361 & 0.000 & 2.708 & $\mathrm{~N}=418$ \\
& between & & 0.196 & 0.000 & 0.881 & $\mathrm{n}=38$ \\
& Within & & 0.305 & -0.759 & 1.949 & $\mathrm{~T}=11$ \\
\hline
\end{tabular}

Debt to asset ratio was the other measure of leverage considered in the study. The debt asset ratio was determined by dividing total liabilities by total assets, the higher the ratio the more the financial distress in the firm. The mean debt to asset ratios over the years 2005, 2006, 2007, 2008, 2009, 2010, 2011, 2012, 2013,2014 and 2015 were found to be $0.835,1.039,1.065,0.768,1,0.805,0.812,1.075,1.064,0.845$ and 0.841 respectively with standard deviations $0.151,1.398,1.38,0.204,1.376,0.159,0.172,1.345,1.262,0.041$ and 0.039 respectively. From the results, the firms also kept high debt to asset ratios. This is the measure that shows the solvency of the firm. In comparison to the quick ratio, the firms seem to have more assets than long-term assets.

Table 4. 3: Debt To Asset Ratio

\begin{tabular}{llllll}
\hline Year & Obs & Mean & Std. & Min & Max \\
\hline 2005 & 38 & 0.835 & 0.151 & 0.274 & 1.076 \\
2006 & 38 & 1.039 & 1.398 & 0.080 & 8.763 \\
2007 & 38 & 1.065 & 1.380 & 0.517 & 8.735 \\
2008 & 38 & 0.768 & 0.204 & 0.088 & 0.918 \\
2009 & 38 & 1.000 & 1.376 & 0.085 & 8.572 \\
2010 & 38 & 0.805 & 0.159 & 0.081 & 0.922 \\
2011 & 38 & 0.812 & 0.172 & 0.084 & 0.937 \\
2012 & 38 & 1.075 & 1.345 & 0.398 & 8.551 \\
2013 & 38 & 1.064 & 1.262 & 0.679 & 8.086 \\
2014 & 38 & 0.845 & 0.041 & 0.763 & 0.930 \\
2015 & 38 & 0.841 & 0.039 & 0.736 & 0.922 \\
\hline
\end{tabular}

The overall mean debt to asset ratio for all the firm in all the 11 years combined was found to be 0.9225 while the overall standard deviation was found to be 0.913 . There is a larger variation of debt to asset ratio within the panels with a standard deviation of 0.871 as compared to the variation between the panels which was only 0.279. This indicates that there is high financial distress risk in each firm over years as compared financial distress risk as measured by debt asset ratio across commercial banks in Kenya. 
The Effect of Financial Leverageas a Financial Distress Factor on Financial Performance on

Table 4. 4: Overall descriptive analysis for debt asset ratio

\begin{tabular}{lllllll}
\hline & & Mean & Std. Dev. & Min & Max & Observations \\
\hline Debt Asset ratio & Overall & $9.225 \mathrm{E}-01$ & 0.913 & 0.080 & 8.763 & $\mathrm{~N}=418$ \\
& between & & 0.279 & 0.477 & 1.569 & $\mathrm{n}=38$ \\
& Within & & 0.871 & -0.493 & 8.181 & $\mathrm{~T}=11$ \\
\hline
\end{tabular}

Considering the overall leverage of the firms which was measured as a latent factor of the 2 indicators debt to equity and debt to asset ratios, the overall mean leverage was found to be $4.830 \mathrm{E}-11$ with slightly high variability. The overall standard deviation of the latent leverage measure was found to be 0.025 which was a contribution of a higher variation within panels than between panels. The standard deviation between panels was 0.011 while within the panels the standard deviation was found to be 0.022.this is consisted with the results when the researcher used the two indicators. This indicates that there is a high financial distress risk caused by leverage across the commercial banks in Kenya over time but not as high as financial distress risk caused by leverage within every commercial bank over time. This may be due to different levels of leverage kept by individual commercial banks.

The results in table 4.5 further show a high dispersion of leverage levels between and within commercial banks as signified by the standard deviation. Of interest are the negative minimum values which were attributed to high leverage levels by some commercial banks resulting to poor financial performance due to high finance cost. The current study's results describes clearly that leverage has a significant distressing negative effect on financial performance for other sources of finance like use of internal reserves other than leverage from external parties, this results concurs with Ongore (2011) whose study examined on whether firms adopted a pecking order theory in financing activities of the firm, the author noted that firms will use internal sources of finance over leverage due to high cost of obtaining external financing (leverage) from Kenya's financial markets. The current study also concurs with Muigai (2016) whose studies also found out that firms will prefer internal equity since use of leverage could result to financial distress however Muigai (2016) carried out the study on non-financial firms listed in NSE.

Table 4. 5: Overall descriptive analysis for leverage

\begin{tabular}{lllllll}
\hline & & Mean & Std. Dev. & Min & Max & Observations \\
\hline Leverage & Overall & $4.830 \mathrm{E}-11$ & 0.025 & -0.128 & 0.159 & $\mathrm{~N}=418$ \\
& Between & & 0.011 & -0.039 & 0.019 & $\mathrm{n}=38$ \\
& Within & & 0.022 & -0.089 & 0.144 & $\mathrm{~T}=11$ \\
\hline
\end{tabular}

\subsection{Descriptive analysis of financial performance}

Financial performance was considered by the researcher as the dependent variable which the study sought to find out the level of its influence due to distress factors. Financial performance was measured based on the indicators return on assets (roa) and return on equity (roe). Table 4.6 presents the descriptive statistics for the measure return on equity as the mean roe for each year across the 11 years. Across the period, the maximum annual mean returns on equity ranged from 0.6088 for the year 2011 and 4.644 in 2012. The mean ROE thus seem to have no linear trend against time with means between 0.344 and 0.5251 . The mean ROE seem to have low variability of below 0.2 except for 2012 and 2013 that had standard deviations of 0.7588 and 0.6784 respectively.

Table 4. 6: Annual Mean Returns on Equity

\begin{tabular}{llllll}
\hline Year & Obs & Mean & Std. & Min & Max \\
\hline 2005 & 38 & 0.3936 & 0.1828 & 0.0221 & 0.9984 \\
2006 & 38 & 0.4000 & 0.1871 & 0.0475 & 1.0265 \\
2007 & 38 & 0.3776 & 0.1543 & 0.0549 & 0.6747 \\
2008 & 38 & 0.3628 & 0.1563 & 0.0763 & 0.6847 \\
2009 & 38 & 0.3458 & 0.13743 & 0.05563 & 0.6100 \\
2010 & 38 & 0.3444 & 0.1138 & 0.1288 & 0.6402 \\
2011 & 38 & 0.3843 & 0.1249 & 0.0701 & 0.6088 \\
2012 & 38 & 0.4881 & 0.7588 & 0.0221 & 4.6439 \\
2013 & 38 & 0.5251 & 0.6784 & 0.1725 & 4.2266 \\
2014 & 38 & 0.3739 & 0.1536 & 0.0000 & 0.7959 \\
2015 & 38 & 0.3584 & 0.1232 & 0.0514 & 0.6308 \\
\hline
\end{tabular}

The overall mean for all the firms for all the years combined was found to be 0.3717 . The overall standard deviation of roe was found to be 0.144 . The variation of roe is larger across the 38 panels of the banks with a standard deviation of 0.11 as compared to the variation across the years within the panels which was only 0.093. In addition from the table 4.7 the overall mean of ROE of 3.72 per cent and overall standard deviation of 14.4 percent, for between 11 and 9 percent for within is an indication that banks are competing among themselves for making profit however their standard deviations are evident that their profit making capacity is

DOI: 10.9790/487X-1907035771 $\quad$ www.iosrjournals.org $\quad 61 \mid$ Page


divergent from each other, this may be as a result of the different levels of financial distress effect on financial performance of commercial banks in Kenya.

Table 4. 7: Overall descriptive analysis for ROE

\begin{tabular}{|c|c|c|c|c|c|c|}
\hline & & Mean & Std. Dev. & Min & Max & Observations \\
\hline \multirow[t]{3}{*}{ Roe } & Overall & $3.717 \mathrm{E}-01$ & 0.144 & 0.000 & 0.998 & $\mathrm{~N}=418$ \\
\hline & between & & 0.111 & 0.110 & 0.549 & $\mathrm{n}=38$ \\
\hline & Within & & 0.093 & -0.123 & 0.821 & $\mathrm{~T}=11$ \\
\hline
\end{tabular}

Figure 4.2 below shows the virtual presentation of the return on equity across the entities for against time for the years 2005 to 2015 . The scatter plot of roe against time depicts a distribution with virtual low variability across the years. The plots of the mean roe Plotting the mean ROE for each year, the line shows a trend line curve that doesn't depict any increasing or decreasing trend of mean roe with time implying possible stationarity across time.

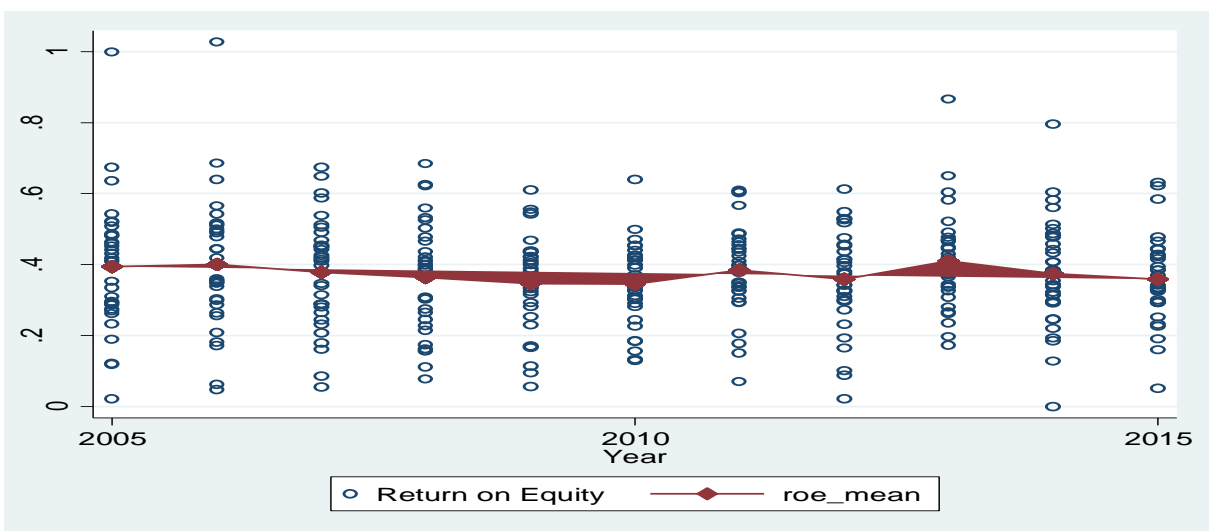

Figure 4. 1: Return on Equity against time

A further analysis used for the performance indicator roe against time was the one way anova to determine if there is a significant difference in mean roe across time. The anova statistics in table 4.8 show that the p-value of the F statistic is 0.000 which is less than 0.05 . This implies that at 0.05 level, the mean roe is significantly different across time. The differences of roe with time does not necessarily imply a linear trend of mean roe with time.

Table 4. 8: ROE One way ANOVA against time

\begin{tabular}{llllll}
\hline & Sum of Squares & Df & Mean Square & F & Sig. \\
\hline Between Groups & 1.450 & 28.000 & 0.052 & 2.931 & 0.000 \\
Within Groups & 5.901 & 334.000 & 0.018 & & \\
Total & 7.350 & 362.000 & & & \\
\hline
\end{tabular}

Considering return on assets which was also used to measure the financial performance of the banks, the descriptive statistics results are shown in table 4.9. The financial institutions seemed to have lower returns on assets as compared to the returns on equity as seen earlier. The mean returns on assets ranged between 0.0517 and 0.0604 which were the mean roa for the years 2012 and 2013. This shows a possibility that the financial institutions do not invest a lot in the assets or realise very little returns from investments in assets. The variability of the returns on assets were also very low with all standard deviations ranging between 0.0136 and 0.0245. he minimum possible return on asset realised by a firm in study across the 11 years was 0.000 in 2014 and the maximum possible roa realised by a firm was only 0.1093 which was in 2006 .

Table 4. 9: Annual Mean Returns on Assets

\begin{tabular}{llllll}
\hline Year & Obs & Mean & Std. & Min & Max \\
\hline 2005 & 38 & 0.0539 & 0.0214 & 0.0052 & 0.0988 \\
2006 & 38 & 0.0551 & 0.0167 & 0.0221 & 0.1093 \\
2007 & 38 & 0.0535 & 0.0136 & 0.0265 & 0.0795 \\
2008 & 38 & 0.0550 & 0.0166 & 0.0196 & 0.0888 \\
2009 & 38 & 0.0565 & 0.0171 & 0.0258 & 0.0993 \\
2010 & 38 & 0.0538 & 0.0166 & 0.0274 & 0.0908 \\
2011 & 38 & 0.0550 & 0.0161 & 0.0260 & 0.0983 \\
2012 & 38 & 0.0517 & 0.0245 & 0.0014 & 0.1024 \\
2013 & 38 & 0.0604 & 0.0161 & 0.0244 & 0.0995 \\
2014 & 38 & 0.0541 & 0.0172 & 0.0000 & 0.0867 \\
2015 & 38 & 0.0524 & 0.0183 & 0.0054 & 0.0864 \\
\hline \multicolumn{7}{r}{ DOI: $10.9790 / 487 X-1907035771$} & www.iosrjournals.org & $62 \mid$ Page
\end{tabular}


Considering the overall mean roa as shown in table 4.10, the financial institutions had a mean return of 0.05469 for all the 11 years jointly. The overall standard deviation was found to be 0.018 which was a contribution of variability between and within panels. Both measures of dispersion for variations between and within panels were found to be low for roa with standard deviations of 0.013 and 0.012 respectively. Low standard deviations imply homogeneity of the banks in regards to the returns on assets realised. This implied that generally all banks had low roe with no banks expected to realise high roa in any of the years. In addition from the table 4.33 the overall mean of ROE of 5.47 per cent and standard deviation 13 percent for between and 12 percent for within is an indication that banks are competing among themselves for making profit however their standard deviations are evident that their profit making capacity is divergent from each other.

Table 4. 10: Overall descriptive for ROA

\begin{tabular}{|c|c|c|c|c|c|c|}
\hline & & Mean & Std. Dev. & Min & Max & Observations \\
\hline ROA & $\begin{array}{l}\text { Overall } \\
\text { between } \\
\text { Within }\end{array}$ & $5.469 \mathrm{E}-02$ & $\begin{array}{l}0.018 \\
0.013 \\
0.012\end{array}$ & $\begin{array}{c}0.000 \\
0.024 \\
-0.020\end{array}$ & $\begin{array}{l}0.109 \\
0.080 \\
0.092\end{array}$ & $\begin{array}{l}\mathrm{N}=418 \\
\mathrm{n}=38 \\
\mathrm{~T}=11\end{array}$ \\
\hline
\end{tabular}

A scatter plot of returns on assets with time including the plots for mean roa shown in figure 4.3 also shows a possible white noise similar to that of roe in figure 4.2 rather than a decreasing or increasing trend of roa with time. Both had virtually constant non increasing trends with uneven decreases and increases across the period. The highest roa is virtually seen to have been in 2013 as it also was with roe. However low the returns of assets was in comparison to the returns on equity, the trends are similar with increases of roa in the same years as the increases realised on roe and drops also in the same years. This implies that the factors influencing and causing improvements in roe could also be the same factors that influence roa.

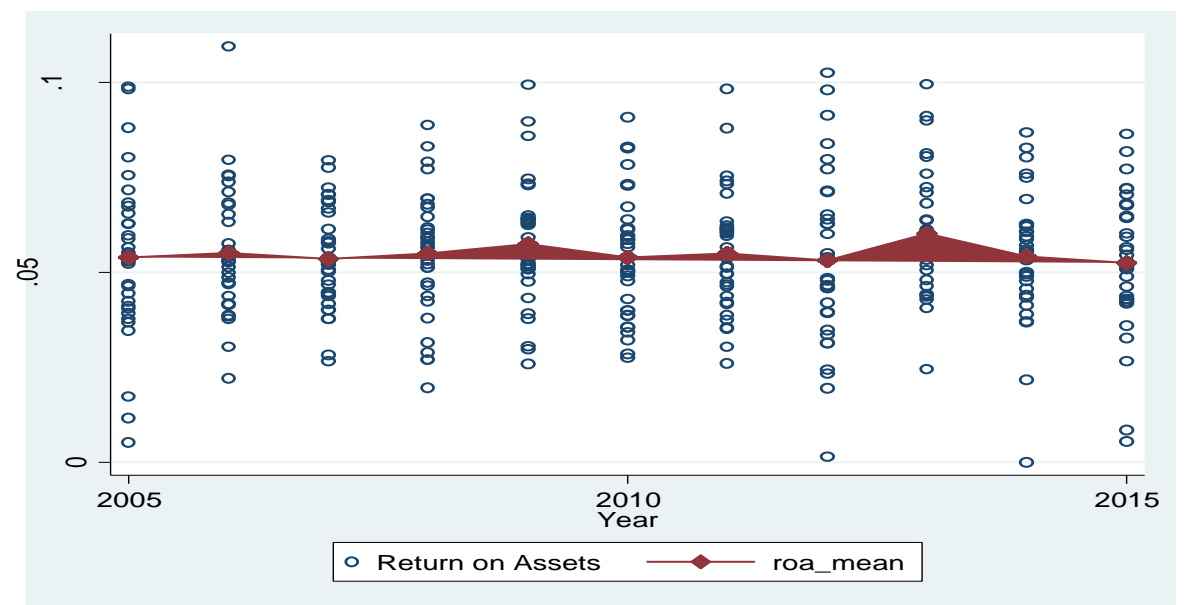

Figure 4. 2: Return on Assets against time

Considering the similarity in the trend similarity of roe and roa based on the graphical presentations, roa however showed no significant difference in means across the years. The $\mathrm{p}$-value of the $\mathrm{F}$ statistics from the anova shown in table 4.11 is 0.610 which is greater than 0.05 implying that at 0.05 level, there is no significant differences in mean roa across time. This could be attributed to the very low amounts of roa realised by all firms across the years.

Table 4. 11: ROA One way ANOVA against time

\begin{tabular}{llllll}
\hline & Sum of Squares & Df & Mean Square & F & Sig. \\
\hline Between Groups & 305.082 & 28.000 & 10.896 & 0.904 & 0.610 \\
Within Groups & 4026.634 & 334.000 & 12.056 & & \\
Total & 4331.716 & 362.000 & & & \\
\hline
\end{tabular}

Considering the overall financial performance of the firms which was measured as a lantent factor of the 2 indicators roe and roa, the overall mean financial performance as found to be 0.007 with slightly high variability as compared to the observed components roa and roe. The overall standard deviation of the latent financial performance was found to be 0.229 which was a contribution of a higher variation across panels than within panels. The standard deviation between panels was 0.177 while within the panels the standard deviation was found to be 0.147 . 
Table 4.36 shows return of equity (ROE) had an average of 0.03717 with overall standard deviations of 0.144 . On the other hand Table 4.12 also shows that profitability as measured by return on assets (ROA) had an average of 0.05469 with overall standard deviations of 0.018 . The minimum ROA within commercial banks was -0.123 indicating some commercial banks reported losses in some years in between 2005-2015. Evidently, ROE was more volatile compared to ROA. This might have been as a result of the effect of financial distress factors to ensure that there are considerable levels of equity in commercial banks. This results are consistent with the studies carried out by Muriithi (2016) who noted that a positive average mean of ROE is an indication that banks are competing among them for making profit however their differing standard deviations of between and within is an evident that their profit making capacity is volatile.

Table 4. 12: Overall financial performance.

\begin{tabular}{lllllll}
\hline & & Mean & Std. Dev. & Min & Max & Observations \\
\hline Financial Performance & overall & $7.776 \mathrm{E}-03$ & 0.229 & -0.732 & 0.653 & $\mathrm{~N}=418$ \\
& between & & 0.177 & -0.399 & 0.338 & $\mathrm{n}=38$ \\
& within & & 0.147 & -0.988 & 0.450 & $\mathrm{~T}=11$ \\
\hline
\end{tabular}

Table 4.13 shows the anova for the overall financial performance measured as an unobserved latent variable from the indicators roa and roe. The anova for financial performance with time shows that financial performance exhibits significantly different means across time at 0.05 level of significance. This is implied by the p-value of 0.000 which is less than 0.05 .

Table 4. 13: Overall performance One way ANOVA against time

\begin{tabular}{llllll}
\hline & Sum of Squares & Df & Mean Square & F & Sig. \\
\hline Between Groups & 1474.355 & 28.000 & 52.656 & 33.986 & 0.000 \\
Within Groups & 517.474 & 334.000 & 1.549 & & \\
Total & 1991.829 & 362.000 & & & \\
\hline
\end{tabular}

Given the differences in mean financial performance with groups of time in years as shown by the analysis of variance, it's key to determine that the differences are not due to an increasing or decreasing trend of financial performance with time. Being the dependent variable, significance in a linear trend of financial performance would imply non-stationarity and the need to de-trend the data before further panel model analysis. To determine whether financial performance exhibits a trend, the study used a unit root test. The stationarity unit-root test was done to confirm whether there is stationary in all panels. The LLC bias-adjusted test statistic $\mathrm{t}$ $* \delta=-24.9766$ is significantly less than zero $(\mathrm{p}<0.00005)$, so we reject the null hypothesis of a unit-root and favour the alternative that panels are stationary.

Table 4. 14: Unit-root test for panel stationarity

\begin{tabular}{lll}
\hline & Statistic & p-value \\
\hline Unadjusted $\mathbf{t}$ & -23.5520 & \\
Adjusted t* & -24.9766 & 0.000 \\
\hline
\end{tabular}

The current study was in agreement with $\mathrm{CBK}(2015)$ report that reported a slight decline in profitability in recent years since commercial banks had a of about 0.054 in 2005 but declined to about 0.052 in 2015 mean. According to CBK (2015) banking supervisory report, the banking sector registered improved financial strength in 2015 , with total net assets recording an increase of $9.2 \%$ per cent. This was attributable to growth in investments and loans and advances, which increased by 23.2 per cent and 15.12 per cent respectively. Despite the improved financial strength, the banking sector registered declined profitability in 2015. The sector recorded a 5.03 per cent decline in pre-tax profits during the year. The decline in profitability in 2015 could be explained by a faster growth in expenses compared to the growth in income. The banks income increased by 9.1 per cent in 2015 compared to a higher increase of expenses of 16.3 per cent. the current study attributes the decline in profitability as the consequences of financial distress factors influencing profitability.

\section{Exploratory analysis of financial performance}

According to Yong and Pearce (2013) exploratory analysis summarizes data in graphs so that relationships and patterns can be easily interpreted and understood. It is normally used to regroup variables into a limited set of clusters based on shared variance. Hence, it helps to isolate constructs and concepts. Exploratory factor analysis tries to uncover complex patterns by exploring the dataset and testing predictions and also exploratory tests provide visual impression of the nature of panel data through graphical presentation. Exploratory tests like spaghetti plot graph, box plot and Mean CI plot were used to establish the presence of outliers as presented by figures 4.1 to 4.5 . 


\section{Return on Equity}

Before examining the relationship between financial distress factors and financial performance of commercial banks as measured by return on equity, the study explored the financial performance among different commercial banks in Kenya over the eleven year period; 2005-2015. The study used the Spaghetti plots, a lowness smoothed plot, box plot and mean plot as shown in Figure 4.4 to Figure 4.7.

\section{Spaghetti plot graph}

Figure 4.3 below shows the virtual presentation of the return on equity across the entities for against time for the years 2005 to 2015. The line spaghetti plot is an overlay of each entities trend roe over time. The plot gives a general indication of the behavior of roe across the entities; it shows a possible heterogeneous nature of commercial banks in Kenya.From the findings, it can be inferred that all commercial banks had different intercept. It can however be observed that the slopes are not significantly different from each other. However there were variations in financial performance as measured by ROE among commercial banks in Kenya under consideration. This preliminary result confirms the absence of time related effects indicating that the appropriate model may be fixed effects model. This type of panel model has non-constant slopes and intercepts that differ according to the cross-sectional (group) meaning there are no temporal effects.

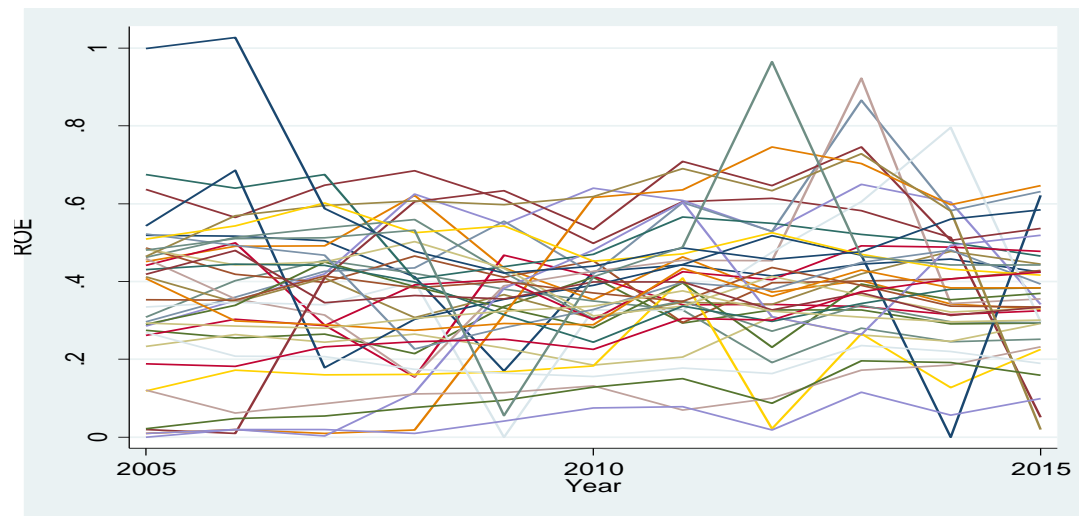

Figure 4. 3Roe over time Spaghetti plot

\section{Box plot graph}

The line in the box represents the median observation while the whiskers shows the largest and least non-outlier observations the observations near the whisker were the near outliers, while those at the extreme are the far outliers. A plot of box plots over time for the variable return on equity shows varying distributions of roe over time. The roe on the first year shows a distribution skewed to the left. The median is above the center of the box and closer to the upper quartile and the lower tail is longer than the upper tail. The second year 2006 and the last year however are probably skewed to the right; they have the median being below the center and the upper tail longer than the lower. Across the years, roe seem to have varying distributions. In order to obtain a relatively normally distributed data-set, all the potential far-outliers were eliminated.

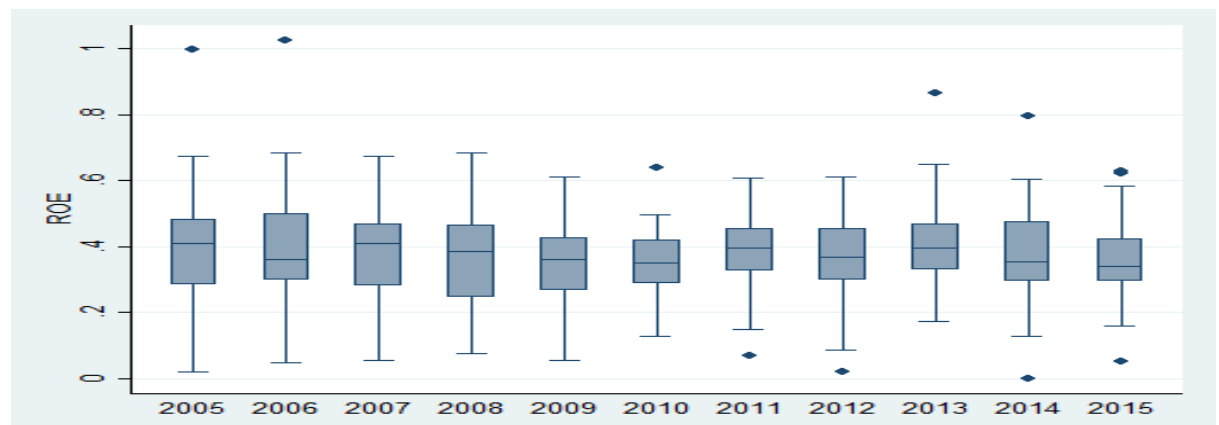

Figure 4. 4Roe over time box plot

\section{Mean plots}

A further graphical analysis of the distribution of roe over time using the mean plots with confidence intervals shows that the indicator probably exhibits heteroscedasticity. Heteroscedasticity of a variable implies constant variance. The confidence intervals over the periods are varying in with some years showing shorter $\mathrm{CI}$ than others implying varying standard deviations over time. 


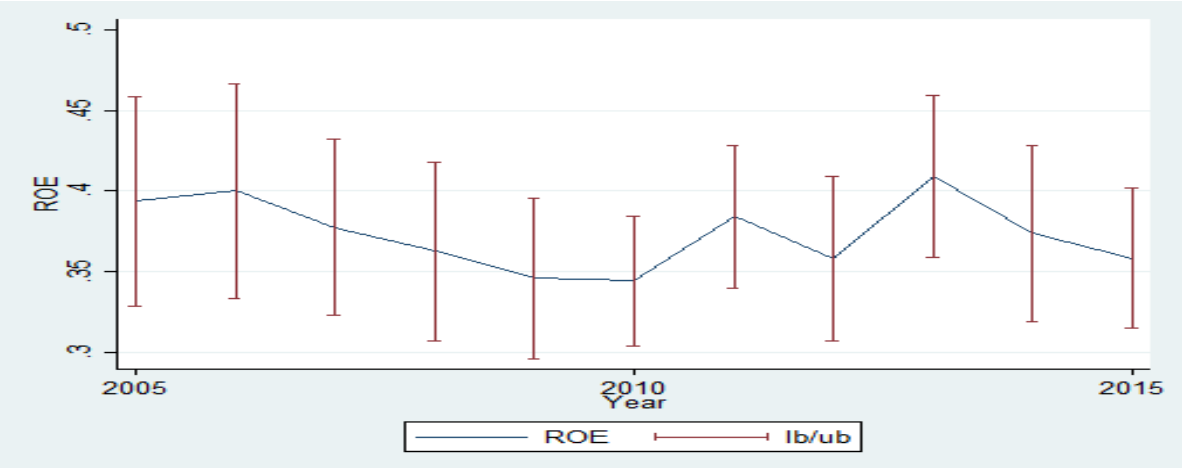

Figure 4. 5Roe over time (mean,CI) plot

\section{Return on Asset}

Before examining the relationship between financial distress factors and financial performance of commercial banks as measured by return on asset, the study explored the financial performance among different commercial banks in Kenya over the eleven year period; 2005-2015. The study used the Spaghetti plots, a lowness smoothed plot, box plot and mean plot as shown in Figure 4.8 to Figure 4.8.

\section{Spaghetti plot}

Figure 4.8 below shows the virtual presentation of the return on equity across the entities for against time for the years 2005 to 2015 . The line spaghetti plot is an overlay of each entities trend roa over time. The plot gives a general indication of the behavior of roa across the entities; it shows a possible heterogeneous nature of the banks

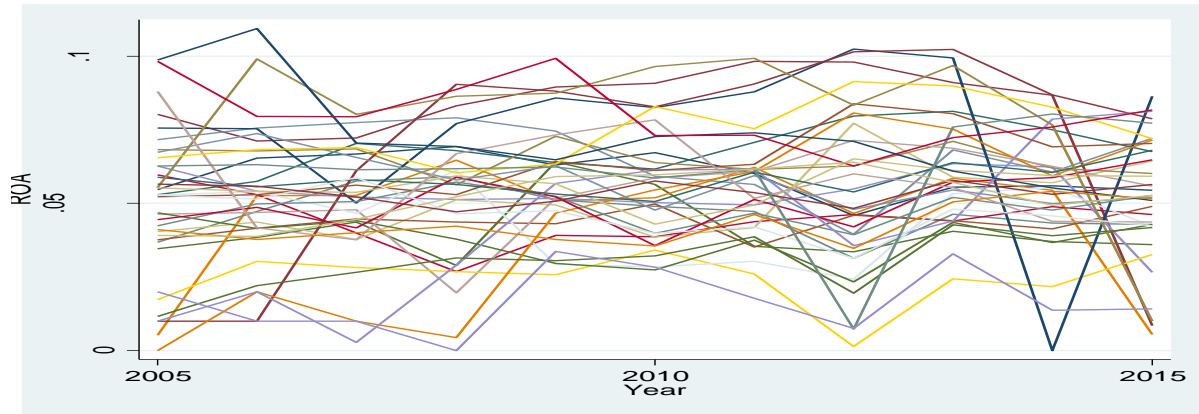

Figure 4. 6 Roa over time Spaghetti plot

\section{Box plot graph}

A plot of box plots over time for the variable return on equity shows slightly varying distributions of roa over time. The distributions across time are similarly not seemingly skewed on either directions but are of varying ranges. The roa across the years shows non-skewed distributions. The medians are all about the centers of the boxes except for the year 2009 that has a median well below the center of the box implying a possible distribution skewed to the right. Across the period though, the interquartile ranges are of varying sizes.

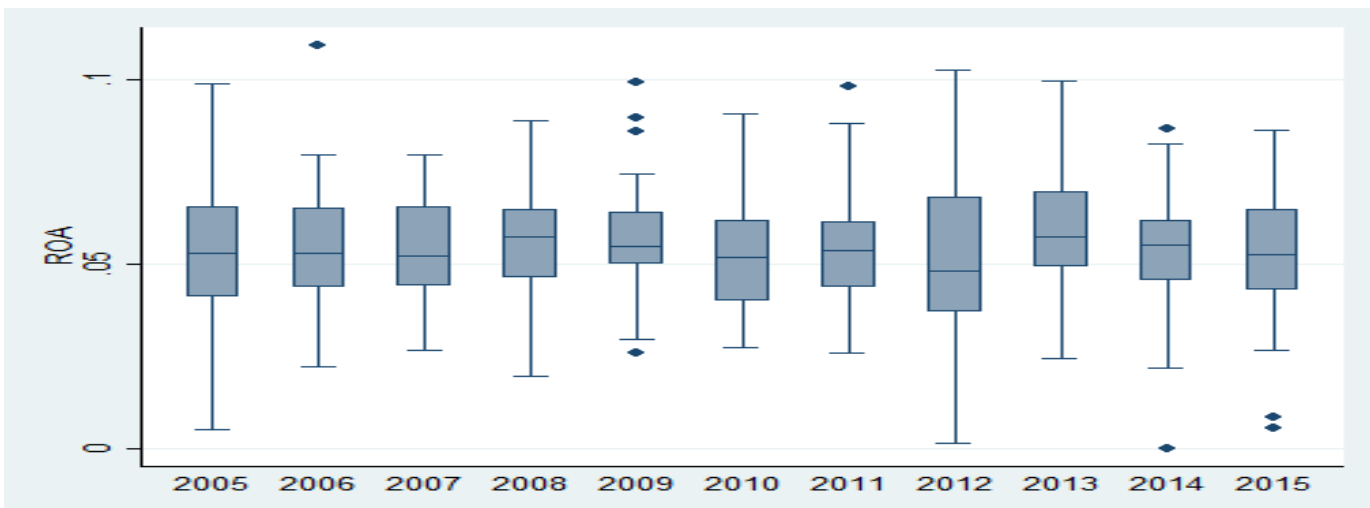

Figure 4. 7Roe over time box plot 
Mean plots

A further graphical analysis of the distribution of roe over time using the mean plots with confidence intervals shows that the indicator probably exhibits heteroscedasticity. Heteroscedasticity of a variable implies constant variance. The confidence intervals over the periods are varying in with some years showing shorter CI than others implying varying standard deviations over time.

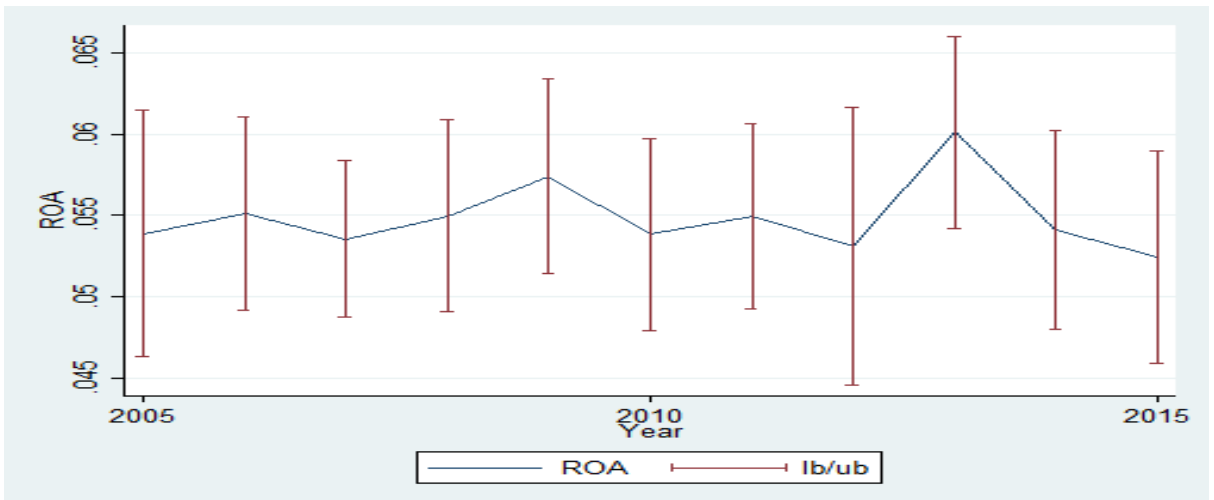

Figure 4. 8Roa over time (mean, CI) plot

\subsection{Inferential Analysis}

The aim of the study was to determine the influence of operational efficiency as a financial distress factor on financial performance of commercial banks in Kenya.Christiano, Rostagno and Motto (2010) argued that factors are score cards on the financial performance of an organization that reflects forces that may cause financial distress and financial performance fluctuations.Inferential analysis was the basis behind which conclusions were drawn for the study objectives. The techniques used for this analysis were to determine the level of influence that operating efficiency has on the dependent variable; being financial performance. The techniques involved bivariate analyses between each independent variable and the dependent variable and thereafter a joint influence analysis by multivariate analysis to determine the joint influence of the financial distress factors on performance of commercial banks.

For inferential analysis statistical models were fitted to determine the influences and relationships. The models fitted considered that the data collected was panel data consisting of both cross sectional a time series components. The data contained cross sections consisting of 38 entities a time period of only 11 years. Each of the entities of the data had information required for all the 11 years implying that the panels were strongly balanced. The general form of the model structure adopted was of the form given by the following equation;

$Y_{i t}=\beta+\beta_{1} X_{i t}+\varepsilon_{i t} \ldots .$. Fixed effect $\quad$ \{equation 4.1 \}

Or

$Y_{i t}=\beta+\beta_{1} X_{i t}+\mu_{i t}+\varepsilon_{i t} \ldots$. . Random effect \{equation 4.2 \}

Where $\mathrm{X}_{\mathrm{it}}$ is the predictor variable and $Y_{i t}$ is the dependent variable. Equation 4.1 the fixed effect model assumes homogeneity of estimates across entities and that the independent variable that influence performance vary over time but have a fixed effect across the entities. The study fitted both the fixed and random effect models basing on ordinary least squares and further tested the appropriate model to be adopted.

\section{Bivariate analysis of Financial leverage and performance of commercial banks}

The researcher also sought to determine the effect of Leverage on the performance of commercial banks in Kenya. For this objective the study also performed a one predictor bivariate fixed effect model and random effect model to evaluate the effect of the model using the Haussmann specification test to show the favorable model of the two. The Haussmann specification test for the bivariate model between Liquidity and performance is shown in table 4.15. The chi-square statistic for the Haussmann test was found to be equal to 0.017 with a p-value of 0.6818 that is greater than 0.05 which suggested that the random effect model was a much better model.

Table 4. 15Haussmann specification; bivariate model with Leverage as predictor

\begin{tabular}{lllll}
\hline & (b) fixed & (B) random & (b-B) Difference & sqrt(diag(V_b-V_B $)$ S.E. \\
\hline Leverage & 0.644 & 0.665 & -0.021 & 0.051 \\
\hline $2(1)=(b-B)^{\prime}\left[\left(V \_b-V \_B\right)^{\wedge}(-1)\right](b-B)=0.17$, & Prob>chi2 $=$ & 0.6818
\end{tabular}

Based on the model choice from the Haussmann LM test, the results of the random effect model are presented in tables 4.16 and table 4.17 showing the model summary and the model coefficients of the model. 
There were a total of 418 observations used in this analysis considering 38 groups of entities implying strongly balance panels. The minimum maximum and average numbers of observations per groups were all equal to 11 . The $R^{2} s$ within, between and the overall $R^{2}$ are $0.0094,0.0144$ and 0.0092 respectively. The $R^{2}$ is generally the variation of the dependent variable performance that is explained by the variation of the predictors in the model. In this model, The $\mathrm{R}^{2}$ within is the goodness of fit measure for the individual mean de-trended data which disregards all the information between groups in the data. The anova statistics measures the general significance of the model. The p-value of the F statistic to the model shows is 0.000 which is less than 0.05 implying that the estimated parameters in the model are at least not equal to zero. This infers that Liquidity have an influence on performance of commercial banks.

Table 4.16: Model Summary Fixed-effects within group variable entity; leverage risks

\begin{tabular}{|c|c|c|c|c|c|c|c|}
\hline \multicolumn{4}{|c|}{ Model Statistics } & \multicolumn{4}{|l|}{ Panel Observations } \\
\hline R-sq: & Within & $=$ & 0.0094 & Number of Obs & & $=$ & 418 \\
\hline & Between & $=$ & 0.0144 & Number of groups & & $=$ & 38 \\
\hline & Overall & $=$ & 0.0092 & & & & \\
\hline \multirow[t]{3}{*}{ Wald } & $\operatorname{chi} 2(1)$ & $=$ & 3.37 & Obs per group: & $\min$ & $=$ & 11 \\
\hline & Prob $>$ chi 2 & $=$ & 0.0663 & & avg & $=$ & 11 \\
\hline & corr(u_i,X) & $=$ & 0 & & $\max$ & $=$ & 11 \\
\hline
\end{tabular}

The coefficients table 4.17 of the study that presents the model coefficients. From the table, the estimated leverage coefficient is significantly not equal to zero $(\beta=0.665, t=1840, p$-value $=0.046)$. At 0.05 level of significance, the P-value was found to be less than 0.05 which indicates that the estimated coefficient is significant. The estimates of the coefficient of leverage shows that a unit increase in leverage ratios would cause the levels of performance to rise by 0.665 units. The standard deviation of the residual within the group is called Sigma_u whereas Sigma_e is the standard deviation of the overall error term. The sigma_u and sigma_e calculates Rho and gives the intra-class correlation. The table shows that the intra-class correlation is 0.555 indicating that $55.5 \%$ of the variance is caused by the differences across panels.

Table 4. 17: Coefficients table; fixed effect model with leverage as predictor

\begin{tabular}{lllll}
\hline & Coef. & Std. Err. & Z & \multicolumn{1}{l}{ P>z } \\
\hline Leverage risks & 0.665 & 0.362 & 1.840 & 0.046 \\
Constant & 0.010 & 0.031 & 0.320 & 0.752 \\
sigma_u & 0.175 & & & \\
sigma_e & 0.156 & & & \\
Rho & 0.555 & & & \\
\hline
\end{tabular}

\subsection{Diagnostic tests Time Fixed Effects}

A joint test could be carried out to determine if dummies for all years are qqual to zero,if they were then no time fixed effects was needed (Torres, 2007). Results in Table 4.18 shows the test results for time fixed effects. The $\mathrm{p}$ value $(0.0000)$ is less that 0.05 indicating that there are no significant time affects and therefore no need to introduce dummy variables.

The study further performed tests on the fixed effect model fitted to ensure that the model meets the assumptions of OLS regression that was used. The tests are important to ensure the reliability of the model fitted before testing hypotheses and drawing conclusions from the model.The study being a fixed effect model, the model was fitted based on the assumption of fixed effects on the entities which is what is tested. Further to the fixed entities the researcher tested for time fixed effect on the model. For this, dummy variables for each of the 11 years were generated and a model fixed effect model fitted including the dummy years variables. Finally a test was done on the model to determine whether the effects of the dummy years are all jointly equal to zero. The analysis yielded results below for the F statistic and it's P-value which was found to be greater than 0.05. This implies that there is no time fixed effect required for the model. All coefficients of time are jointly equal to zero.

\section{Cross-sectional dependence}

The multivariate model fitted for this study was found to exhibit cross-sectional dependence thus violating the assumption of cross-sectional independence. This was tested using the Breusch-Pagan Lagrangian multiplier test for cross-sectional independence that uses a chi-square statistic as shown in table 4.18. The pvalue of the chi-square is 0.000 which is less than 0.05 implying cross-sectional dependence. 


\section{Heteroscedasticity}

The study tested the null hypothesis that the variances of the error term were equal for all time periods. A Wald chi-square test was used to test for group wise homoscedasticity. The null hypothesis tested was rejected at 0.05 level of significance due to the $\mathrm{p}$-value of the chi-square statistics that was found to be 0.000 denoting presence of heteroscedasticity and violation of group wise homoscedastic error terms.

A plot of the mean predicted distrubance terms shows that the mean disturbances vary in expectation over time. Them mean disturbances are above zero for mos of the years thought they drop below zero in the years 2011 and 2012. The confidence intervals of the disturbance terms are also of varrying ranges implyng varying standard deviations and thus changing variances the confidence intervals of the distubance in 2005 is well shorter compared to the confidence inervals in the years 2010, 2011 and $2014 \mathrm{in}$. Non-constant variances in the disturbance terms implyies a possible problem of heteroscedasticity of the errors. A further statistical test would be required to test the significance of heteroscedaticity of the residuals.

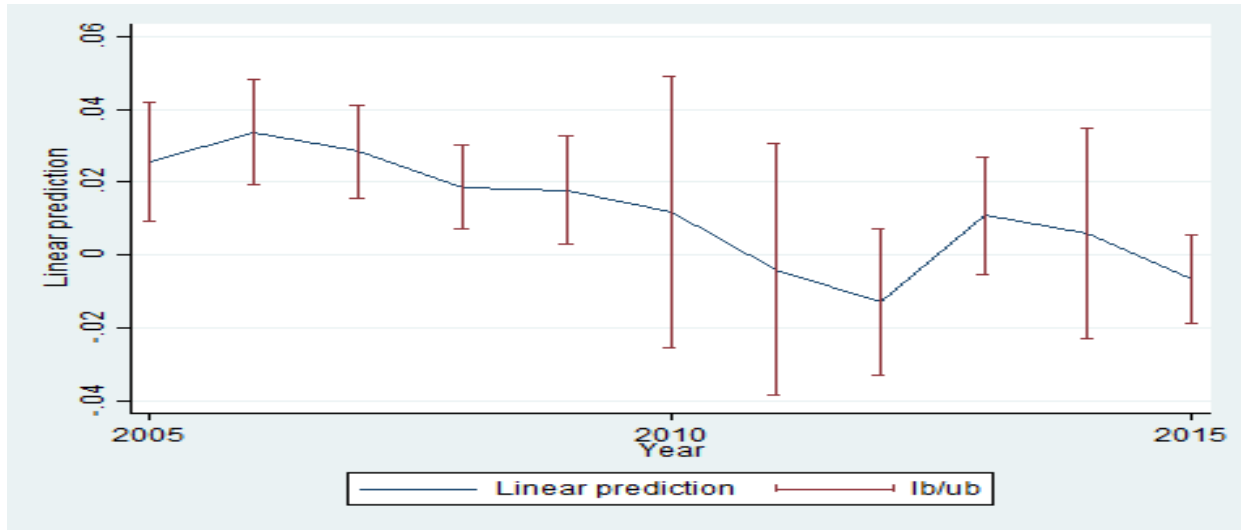

\section{Serial correlation}

Another assumption of OLS regression is the non-serial correlation of the error term. The consistency of the fitted model with the non-serial correlation assumption was also tested. A Wooldrige test was used which is test for the existence of first order autocorrelation in panel data. This test is done by computation of an Fstatistic to test the null hypothesis that there is no existence of first order autocorrelation. The $\mathrm{p}$-value of the fstatistic was found to be 0.198 which is greater than 0.05 implying that the disturbance term of the multivariate data fitted does not exhibit first order autocorrelation.

\section{Normality tests}

The normality test used the Jacque Bera approach for normality test which is based on the consideration that a Gaussian distribution of the error terms should have a mean of 0.000 , a skewness of 0.000 and a kurtosis of 3 . The Jacque Bera approach tests the deviation of the skewness from 0.000 an Kurtosis from 3 using a chi-square statistic. The p-values of the chi-square statistics for both $\mathrm{u}$ and e were found to be greater than 0.05 implying normality in bothcases.

Table 4. 18Diagnostic tests

\begin{tabular}{|c|c|c|}
\hline Test & Test statistic & P-value \\
\hline Time fixed effect () & $\mathrm{F}(10,315)=1.45$ & Prob $>F=0.1567$ \\
\hline Cross-sectional dependence (Pesaran's test) & $P=2.665$ & $\operatorname{Pr}=0.0077$ \\
\hline GroupWise Heteroskedasticity & Wald chi2 $(33)=1491.65$ & Prob $>$ chi $2=0.000$ \\
\hline $\begin{array}{l}\text { First order autocorrelation in Panels } \\
\text { (Wooldridge test) }\end{array}$ & $\mathrm{F}(1,38)=1.729$ & Prob $>F=0.198$ \\
\hline $\begin{array}{l}\text { Joint test for Normality on e } \\
\text { (Jacque Bera) }\end{array}$ & $\operatorname{Chi} 2(2)=3.18$ & Prob $>$ chi $2=0.204$ \\
\hline $\begin{array}{l}\text { Joint test for Normality on } \mathrm{u} \\
\text { (Jacque Bera) }\end{array}$ & Chi2(2) $=192.96$ & Prob $>$ chi $2=0.051$ \\
\hline
\end{tabular}

\subsection{Hypothesis testing}

The final multivariate GLS fitted model was considered better model compared to the OLS model which violated the assumptions. The GLS model taking care of the violations was considered a more robust model and was used to test the hypotheses of the study.

$\mathbf{H}_{\mathbf{0 1}}$ : Leverage has no influence on financial performance of commercial banks in Kenya Considering the fitted GLS model, the p-value of the t-statistic for the estimated coefficient of leverage is 0.000 which is less than 0.05 . The null hypothesis was rejected at 0.05 significance level and a conclusion drawn that 
leverage has a significant influence on performance of commercial banks in Kenya. This result agree with Okello (2015) who concluded that leverage was the strongest determinant of the financial risk of the listed companies and could easily influence financial distress in listed companies in Kenya since more debt financing implies higher possibilities of default hence higher risk. However Okello (2015) only linked leverage as a risk factor on the listed companies in NSE and not on banking industry. Tan (2012)found out that firms with low financial leverage perform better than firms with high financial leverage. Additionally, the study established that the Asian Financial Crisis of 1997-1998 magnified the negative relationship between financial distress and firm performance. High leverage firms were found to experience worse performance during a crisis. The study however was mainly based on the Asian financial crisis and findings could not be generalized for Kenyan banking industry.

The current study also was in agreement with Kosikoh (2014) who found out that there exist a positive relationship between leverage and financial distress and financial performance on Insurance companies in Kenya. However the study only emphasized on the relationship between leverage and financial distress for insurance companies in Kenya The current study also concurs with Demirhan (2014) who also found out that leverage as financial distress factor has a positive relationship with financial performance. Demirhan (2014) found that high leverage was inversely correlated with firm financial performance during financial crisis period and managing a reasonable amount of debt in the capital structure should be another consideration for finance managers.

However Nyamboga,Ongesa,Omwario,Nyamweya,Muriuki and Murimi(2014)based non-financial firms listed in NSE, disagreed that leverage does not have significant influence on corporate financial distress and financial performance. The findings also contradicted those of Hussain and Fayyaz (2015); Innocent and Nnagbogu (2014)who found that financial leverage has a significant negative relationship with firm's performance, measured by ROA in a study based on commercial banks in Pakistan and Nigeria respectively. The current study also disagreed with Chinedu and Nnagbogu( 2014) who in their study of the effect of financial leverage on financial performance of companies in Nigeria found out that financial leverage has no significant effect on financial performance of the sampled companies in Nigeria.

\section{Summary, Conclusion And Recommendations}

\subsection{Summary}

\section{Effect of operational efficiency on financial performance of commercial banks in Kenya}

The current study sought to establish the effect of financial leverage as a financial distress factor on financial performance of the commercial banks in Kenya. Leverage was found to have an influence on performance of commercial banks in Kenya. According to the findings, leverage which was measured in terms of debt equity ratio and debt asset ratio was found to have overall means of 0.122 and 0.923 respectively for the 2 indictors across entities across years. The overall measure of leverage was found to have a positive influence on performance of commercial banks in Kenya. The final combined generalised least squares model results showed a significant positive coefficient of leverage in the model $(B=0.284, z=1.79, p=0.041<0.05)$ implying significance influence of leverage on performance of commercial banks.

The findings revealed that Leverage has a significant negative effect on the financial performance of commercial banks in Kenya both in the short run and in the long run. As a result high leverage reduces profitability of commercial banks.

\subsection{Conclusions and Recommendation}

The study also sought to determine the influence of leverage on financial performance of commercial banks in Kenya. The study conducted analyses and results used to test the hypothesis from which a conclusion was drawn that leverage has a significant influence on the financial performance of commercial banks in Kenya. The study found that leverage is a financial distress factor and hampers financial performance of commercial banks in Kenya. Companies' management should ensure that financial decisions made by them are in consonance with shareholders' wealth maximization objectives which encompasses the profit maximization objective of the firm. The amount of debt finance in the financial mix of the firm should be at the optimal level so as to ensure adequate utilization of the firms' assets and reduce the effect of financial distress on financial performance. Therefore, managers should employ financial leverage in a way that enhances value for their company owners' that will lead to an increase in returns to equity holders of commercial banks, other than being a financial distress factor affecting the financial performance negatively.

\section{Suggestion For Further Study}

This study analyzed the effect of financial distress factors on the financial performance of commercial banks. It is therefore recommended that future studies be carried out on the effect of financial performance on financial leverage as financial distress factor of commercial banks in Kenya. 


\section{References}

[1] Anjum, S., \& Malik, Q. A. (2013). Determinants of Corporate Liquidity - An Analysis of Cash Holdings. IOSR Journal of Busisness and Management, 7(2), 94-100.

[2] Arif, A. (2012). Liquidity risk and performance of banking system. Journal Of Financial Regulation and Compliance, 20(2), 182195 .

[3] Blumberg, B., Donald Cooper, \& Schindler, P. (2014). Business Research Methods (12th ed.). Boston: McGraw-Hill Higher Education

[4] Chinedu, I., \& Nnagbogu, E. (2014). The Effect of Financial Leverage on Financial Performance: Evidence of Quoted Pharmaceutical Companies in Nigeria . IOSR Journal of Economics and Finance, 5(3), 17-25.

[5] Christiano, L., Rostagno, M., \& Motto, R. (2010). Financial factors in economic fluctuations. Working Paper Series.

[6] Demirhan, H. G. (2014). Financial Factors Affecting the Financial Performance of the Firms During the Financial Crisis: Evidence from Turkey. The Strategic Research Journal, 5(1), 65-80.

[7] Eckbo, E. (2008). Empirical Corporate Finance (first Edit). Amsterdam, The Netherlands: Library of Congress Cataloging-inPublication Data.

[8] Eugene, F., \& French, K. (2002). Testing Trade - Off and Pecking Order Predictions about Dividends and Debt. The Review of Financial Studies, 15(1), 1-33.

[9] Fan, J., Titman, S., \& Twite, G. (2012). An International Comparison of Capital Structure and Debt Maturity Choices. Journal of Financial and Quantitative Analysis, 47(01), 23-56.

[10] Foong, S. (2012). Leverage, product diversity and performance of general insurers in Malaysia. The Journal Of Risk Finance, 13(4), 347-361.

[11] Heikal, M., Khaddafi, M., \& Ummah, A. (2014). Influence Analysis of Return on Assets (ROA), Return on Equity (ROE), Net Profit Margin (NPM), Debt To Equity Ratio (DER), and current ratio (CR), Against Corporate Profit Growth In Automotive In Indonesia Stock Exchange. International Journal of Academic Research in Business and Social Sciences, 4(12), 2222-6990. http://doi.org/10.6007/IJARBSS/v4-i12/1331

[12] Hussain, Z., \& Fayyaz, M. (2015). Effect of Financial Leverage on Performance of the Firms : Empirical Evidence from Pakistan. SPOUDAI Journal of Economics and Business, 65(1), 87-95.

[13] James, D., Fama, E., \& Kenneth, F. (2000). Characteristics,Covariance and Average Returns. The Journal of Finance, 55(1), 389406.

[14] Kosikoh, J. C. (2014). Determinants of Financial Distress in Insurance Companies in Kenya. Jomo Kenyatta University of Agriculture and Technology.

[15] Kraus, A., \& Litzenberger, R. H. (1973). A State - Preference Model of Optimal Financial Leverage. The Journal Of Finance, 28(4), 1973.

[16] Modigliani, F., \& Miller, M. H. (1963). American Economic Association Corporate Income Taxes and the Cost of Capital. The American Economic Review, 53(3), 433-443.

[17] Muigai, G. (2016). Effect of Capital Structure on Financial Distress of Non-Financial Companies Listed in Nairobi security Exchange. Jomo Kenyatta University of Agriculture and Technology.

[18] Muriithi, J. (2016). Effect of Financial Risk on Financial performance of Commercial Banks in Kenya.

[19] Nyamboga, T. O., Omwario, B. N., \& Muriuki, A. M. (2014). Determinants of Corporate Financial Distress: Case of NonFinancial Firms Listed in the Nairobi Securities Exchange. Research Journal Of Finance and Acoounting, 5(12), $193-207$.

[20] Okello, C. A. (2015). Determinants of Financial Risk of Listed Companies on Nairobi Security Exchange In kenya.

[21] Omondi, M., \& Muturi, W. (2013). Factors Affecting the Financial Performance of Listed Companies at the Nairobi Securities Exchange in Kenya. Research Journal of Finance and Accounting, 4(15), 99-104.

[22] Ongore, V. (2011). The relationship between ownership structure and firm performance: An empirical analysis of listed companies in Kenya. African Journal of Business Management, 5(6), 2120-2128. http://doi.org/10.5897/AJBM10.074

[23] Opler, T. C., \& Titman, S. (1994). Financial Distress and Corporate Performance. The Journal Of Finance, 49(3), 1015-1040. http://doi.org/10.2307/2329214

[24] Pranowo, K., \& Manurung, A. H. (2010). The Dynamics of Corporate Financial Distress in Emerging Market Economy : Empirical Evidence from the Indonesian Stock Exchange 2004-2008. Eurepean Journal of Social Science, 16(1), 138-149.

[25] Razak, F. (2012). Leverage , product diversity and performance of general insurers in Malaysia. The Journal of Risk Finance, 13(4), $347-361$.

[26] Saleh, R. Z. A. S. (2015). Dynamic performance, financial leverage and financial crisis : evidence from GCC countries. EuroMed Journal Of Business, 10(2), 147-162.

[27] Senbet. (2012). Corporate Financial Distress and Bankruptcy: A Survey. Forthcoming,Foundations and Trends in Financerends in Finance, 1(July), 251-282.

[28] Shyam-sunder, L., \& Myers, S. C. (1999). Testing static tradeoff against pecking order models of capital structure. Journal of Financial Economics, 51(1), 219-244.

[29] Stewart, M. (1984). The Capital Structure Puzzle. The Journal of Finance, 39(3), 575-592.

[30] Stewart, M., \& Nicholas, M. (1984). Corporate financing and investment decisions when firms have information that investors do not have. Journal of Financial Economics, 13(1), 187-221.

[31] Tan, T. K. (2012). Financial Distress and Firm Performance : Evidence from the Asian Financial Crisis. Journal of Finance and Accountancy, 1(1), 1-11.

[32] Wang'ombe, Muturi, W., \& Ngugi, P. (2016). Asset Quality and Intermediation Efficiency: A Study of Deposit Taking Saving and Credit Co-operative Societies in Kenya. Journal of Emerging Issues in Economics,Finance and Banking(JEIEFB), 5(2), 1843-1859.

[33] Wieland, S., Scott, B., Wieland, S., \& Flavel, B. S. (2015). The relationship between employee orientation , financial performance and leverage. Social Responsibility Journal, 11(4), 716-733.

[34] Yong, A. G., \& Pearce, S. (2013). A Beginner's Guide to Factor Analysis: Focusing on Exploratory Factor Analysis. Tutorials in Quantitative Methods for Psychology, 9(2), 79-94.

Fred O. Sporta. "The Effect of Financial Leverageas a Financial Distress Factor on Financial Performance on Commercial Banks in Kenya." IOSR Journal of Business and Management (IOSR-JBM) 19.7 (2017): 57-71. 